DOI 10.37882/2223-2982.2021.04.09

\title{
ОБЩАЯ ХАРАКТЕРИСТИКА И НЕКОТОРЫЕ ОСОБЕННОСТИ ФОРМИРОВАНИЯ ПРОФЕССИОНАЛЬНО-ЭТИЧЕСКОЙ КОМПЕТЕНТНОСТИ У СТУДЕНТОВ ВУЗОВ
}

\section{GENERAL CHARACTERISTIC AND SOME FEATURES OF THE FORMATION OF PROFESSIONAL AND ETHICAL COMPETENCE IN UNIVERSITY STUDENTS}

M. Garaev

Summary: The analysis of some modern approaches to the study of the formation and development of professional and ethical competence of students of higher educational institutions of various profiles. The functional structure of professional ethics is considered as a characteristic of this ethics in the context of the analysis of the cofunctional blocks of professional ethics functions and key terms that characterize these functions. It is shown that, despite some difference in professional and ethical competence for university education of specialists of various profiles, the functional structure of professional ethics is quite general. Some of the specificity of the formation and development of professional and ethical competence in these students is associated with the peculiarities of the determinants of the system of professional moral norms in their future labor activity.

Keywords: professional and ethical competence, components, functions of professional ethics, university students, legal ethics, bioethics, deontology.
A нализируя понятие «профессиональная этика», исходят из того, что профессиональная этика является наукой о профессиональной морали, а профессиональная мораль рассматривается в виде совокупности идеалов и ценностей, идей о должном, этических принципов и норм поведения, которые а) отражают сущность профессии; б) обеспечивают отношения между людьми в процессе профессиональной деятельности [1].

При изучении формирования и развития профессионально-этической компетентности студентов высших учебных заведений следует исходить из того, что обеспечение качества такой подготовки предусматривает осознание будущими специалистами различного профиля профессионального долга и соблюдения нормативных морально-этических принципов поведения (профессионально-этической компетентности).

В связи с этим, формирование и развитие профессионально-этической компетентности, актуальное для студентов различных учебных заведений, должно осно-
Гараев Марсель Имамутдинович

К.п.н., старший преподаватель, ФГКОУ ВО «Казанский юридический институт МВД России»

m_garaev83@mail.ru

Аннотация: Проведен анализ некоторых современных подходов к исследованию формирования и развития профессионально-этической компетентности студентов высших учебных заведений различного профиля. Рассмотрена функциональная структура профессиональной этики как характеристика этой этики в контексте анализа кофункциональных блоков функций профессиональной этики и ключевых терминов, характеризующих эти функции. Показано, что, несмотря на некоторое различие профессионально-этической компетентности для вузовского обучения специалистов различного профиля, функциональная структура профессиональной этики носит достаточно общий характер. Некоторая специфика формирования и развития профессионально-этической компетентности у этих студентов, связана с особенностями детерминант системы профессиональных моральных норм в их будущей трудовой деятельности.

Ключевые слова: профессионально-этическая компетентность, компоненты, функции профессиональной этики, студенты вузов, юридическая этика, биоэтика, деонтология.

вываться на следующих компонентах:

а) усвоении будущими специалистами этических знаний;

б) овладении соответствующими умениями, навыками;

в) осознании морально-этических ценностей, норм морали и этики;

г) сложившихся чертах характера и направленности личности;

д) приобретенном практическом опыте [2].

Для характеристики профессиональной этики значительный интерес представляет изучение ее этических функций, в силу мультивариативности определяющих их факторов, которые отражают сущность, содержание и направленность профессии.

На основании характеристик этики профессиональных коммуникаций для специалистов по связям с общественностью [1] и профессиональной этики юриста [3] мы проанализировали возможную функциональную 
структуру профессиональной этики (Таблица 1). При этом близкие по своей направленности функции профессиональной этики мы объединили в кофункциональные блоки, а сущность самих функций профессиональной этики определяли в виде совокупности ключевых слов, присущих для характеристики каждой из функций. Такой подход, с нашей точки зрения, лучше позволяет отразить целесообразность построения системы кофункциональных блоков при общей характеристике функциональной структуры профессиональной этики.

Как следует из таблицы 1, функциональная структура профессиональной этики включает в себя 8 кофункциональных блоков (19 функций профессиональной этики), различающихся по совокупности ключевых слов, но зачастую имея одни и те же или близкие по смыслу ключевые слова (ключевые термины), рассматриваемые нами как системообразующие термины в данном контексте.

Помимо общей характеристики, с нашей точки зрения, целесообразно остановиться и на некоторых спец- ифических особенностях формирования и развития профессионально-этической компетентности у студентов высших учебных заведений различного профиля. Относительная специфика процесса формирования и развития профессионально-этической компетентности у студентов вузов может проявляться при анализе особенностей специфических вариантов обучения, реализации и детерминант профессиональных моральных норм в их будущей трудовой деятельности.

Юридическая этика рассматривается как достаточно специфический вариант профессиональной морали, ориентированный на анализ морали юридической сферы трудовой деятельности.

К специфике трудовой деятельности юристов относят:

1. подробную регламентацию их деятельности законом;

2. гласность, контроль деятельности юристов общественностью;

Таблица 1.

Функциональная структура профессиональной этики

\begin{tabular}{|c|c|c|}
\hline Наименование кофункционального блока & $\begin{array}{l}\text { Наименование функции } \\
\text { профессиональной этики }\end{array}$ & Ключевые слова (термины), характеризующие функцию \\
\hline \multirow[t]{2}{*}{ Социально- социализирующий } & Социальная & $\begin{array}{l}\text { Условия, функционирование специалиста, профессиональная сфера, } \\
\text { общество }\end{array}$ \\
\hline & Социализирующая & Профессионал, приобщение общество, система ценностей и морали, \\
\hline \multirow[t]{3}{*}{$\begin{array}{l}\text { Информационно- координационно- раци- } \\
\text { онализирующий }\end{array}$} & Информационная & $\begin{array}{l}\text { Специалист, приобщение, система профессиональных ценностей, про- } \\
\text { фессиональная мораль }\end{array}$ \\
\hline & Координирующая & Профессиональная деятельность, сотрудничество \\
\hline & Рационализирующая & Специалист, цели, методы, средства, принятие решений \\
\hline \multirow{3}{*}{$\begin{array}{l}\text { Превентивно- } \\
\text { прогностический }\end{array}$} & Превентивная & Профессионал, организация, общество, вред \\
\hline & Прогностическая & Прогноз, сотрудник, коллектив, действия, поведение \\
\hline & Разрешения противоречий & Профессиональная деятельность, устранение противоречий \\
\hline \multirow[t]{2}{*}{ Организационно-управляющий } & Организационная & Сотрудник, партнер, трудовая деятельность \\
\hline & Управляющая & Сотрудник, партнер, профессиональная задача управление \\
\hline \multirow{3}{*}{$\begin{array}{l}\text { Регуляторно- оценочно-регламентирую- } \\
\text { щий }\end{array}$} & Регулятивная & Специалист, профессия, регулирование поведения \\
\hline & Оценочная & $\begin{array}{l}\text { Специалист, моральные нормы, цели, задачи, средства, поведение, на- } \\
\text { мерение, действие, }\end{array}$ \\
\hline & Регламентирующая & Профессиональная деятельность, выбор, цели, методы, средства \\
\hline \multirow[t]{2}{*}{ Коммуникативно- воспитательный } & Коммуникативная & Сотрудник, клиент, общение \\
\hline & Воспитательная & $\begin{array}{l}\text { Специалист, профессионал, клиент, социальное окружение клиента, вос- } \\
\text { питание }\end{array}$ \\
\hline \multirow[t]{2}{*}{ Мотивационно - воспроизводственный } & $\begin{array}{l}\text { Мотивационная } \\
\text { (ценностно-ориентирующая) }\end{array}$ & Мотив деятельности, профессионал, социум, \\
\hline & Воспроизводственная & Подобное действие, подобная ситуация, воспроизводение \\
\hline \multirow[t]{2}{*}{ Стабилизационно-модифицирующий } & Стабилизирующая & Профессиональные отношения, уровни, стабилизация \\
\hline & Оптимизирующая & Статус профессии, эффективность профессиональной деятельности \\
\hline
\end{tabular}


3. особую правовую ответственность за свои действия и решения вне сферы профессиональной деятельности;

4. мультивариативность (мультиспецифичность) юридической этики: этика сотрудников органов внутренних дел (следователи и т.д.) (Кодекс профессиональной этики сотрудника органов внутренних дел Российской Федерации), адвокатская этика (Кодекс профессиональной этики адвоката), прокурорская этика (Кодекс этики прокурорского работника Российской Федерации, судейская этика (Кодекс судейской этики), профессиональная этика нотариуса (Профессиональный кодекс нотариусов Российской Федерации), профессиональная этика таможенника (Кодекс этики и служебного поведения должностных лиц таможенных органов Российской Федерации) [3].

У студентов юридических высших учебных заведений вуза в процессе освоения основ этического регулирования профессиональной юридической деятельности формируется самостоятельная этико-правовая позиция на духовно-нравственной основе их личности, а также психологические мировоззренческие и социально-психологические жизненно-практические установки [4].

Особенностью получения высшего образования таможенников является тот факт, что специалистов, работающих в таможенной сфере, готовит не только ведомственный вуз Федеральной таможенной службы - Российская таможенная академия и ее филиалы, но и вневедомственные высшие учебные заведения различного профиля. Это вузы экономического профиля Московский гуманитарно-экономический университет, Таганрогский институт управления и экономики, и некоторые другие вузы, например, Казанский кооперативный институт Российского университета кооперации и др. В высшем учебном заведении, обучающем будущих таможенников, для развития у студентов-будущих таможенников нравственных качеств в процессе их профессиональной подготовки обеспечивают следующие оптимальные условия:

а) операциональные, позволяющие осваивать оперирование с объектами с применением применяя при этом определенных (профессиональных) умений;

б) информационные;

в) социальные;

г) мотивационные, развивающие потребностно-мотивационную сферу студентов, с позиций индивидуальных особенностей личности в профессиональном аспекте;

д) методические, включающие наличие адекватной воспитательно-профессиональной среды, влияющей посредством использования традиционного, институциального, рефлексивного механизмов, обеспечивающих организацию процесса развития профессионально-нравственных качеств [5].

К компонентам профессионально-этической компетенции курсанта военного вуза относят ценностномотивационный (формирование мировоззренческих, политических, патриотических и правовых ценностных установок), когнитивный (обучение когнитивным процессам, профессионально-этические знания, понимание, применение, анализ, синтез и т.д.), деятельностный (освоение культуры профессиональной речи и профессионального общения, эстетики внешнего облика и т.д.) и личностный, реализуемый через эстетическую и этическую сферу нравственного воспитания [6].

Функциональное развитие профессиональной компетентности педагога, с точки зрения А.А. Печеркиной с соавторами, имеет определенную этапность, что мы расцениваем как проявление некоторой специфики данного процесса. В частности, функциональное развитие профессиональной компетентности на начальных стадиях профессионального становления педагога (формирование) имеет относительную автономность, а на стадии самостоятельного выполнения профессиональной трудовой деятельности (становление) компетентность имеет тенденцию объединения с профессионально важными качествами. При этом основными характеристиками профессиональной компетентности становятся обученность, профессиональная подготовленность, профессиональный опыт и профессионализм [7].

Профессиональная компетентность специалиста с высшим медицинским образованием предполагает осуществление трудовой деятельности в соответствии с этическими нормами и элементарными правилами поведения врача. Эти правила студенты медицинских высших учебных заведений изучают при освоении таких дисциплин как этика, биоэтика, деонтология. К основным из этих правил относят: честность и добросовестность в исполнении трудовых обязанностей, недопустимость извлечения личных материальных выгод и рекламирования из корыстных соображений лекарственных средств и медицинских материалов [8]. Появление биоэтики, как современной формы традиционной профессиональной биомедицинской этики, увязывают с технологизацией современной медицины и с проблемой обеспечения сохранения биосоциальной жизни человеческого рода, а также - ответственности за действия человека при взаимодействии с окружающей средой [9]. Как одну из важнейших характеристик профессионально - этической компетентности фармацевтов мы видим в реализации принципов биоэтики в профессиональном обучении и практической деятельности фармацевтов, предложенных О.М. Терновой [10], которая отводит особую роль системе непрерывного образования в решении глобальных проблем социально-нравственного развития 
фармации.

Таким образом, формирование и развитие профессионально-этической компетентности студентов высших учебных заведений предусматривает осознание будущими специалистами различного профиля профессионального долга и соблюдения нормативных морально-этических принципов поведения (профессионально-этической компетентности). Несмотря на некоторое различие профессионально-этической компетентности для вузовского обучения специалистов различного профиля, функциональная структура профессиональной этики носит достаточно общий характер. Однако существует и некоторая специфика формирования и развития профессионально-этической компетентности у этих студентов, проявляющаяся в особенностях детерминант системы профессиональных моральных норм в их будущей трудовой деятельности.

\section{ЛИТЕРАТУРА}

1. Скворцова В.Н. Профессиональная этика. Учебное пособие. Томск: Изд-во ТПУ, 2006. - 180 с.

2. Дудікова Л.В. Професійно-етична компетентність майбутніх лікарів як предмет сучасних вітчизняних досліджень. Науковий огляд: міжнар. наук. журн. Київ: ТК Меганом, 2017. - №9(41). С.58-70.

3. Корнакова С.В. Основы этики. Профессиональная этика юриста: учебник. - Иркутск: Изд-во БГУЭП, 2012. - 308 с.

4. Анисина С.С. Концептуально-методологические основы преподавания профессиональной этики юриста // Научно-методический электронный журнал «Концепт». 2014. Т. 20. C. 796-800. - URL: http://e-koncept.ru/2014/54423.htm.

5. Грязнова Е.Д. Формирование нравственно-этических ценностей у будущих государственных служащих (таможенников) кап основы высококачественной профессиональной деятельности // Вестник костромского государственного университета им. Н.А. Некрасова. Серия: Педагогика. Психология. Социальная работа. Ювенология. Социокинетика. 2013.Т.19, №2. С. 55-58.

6. Маленков А.О. Теоретическая модель формирования профессионально-этической компетентности курсантов военного вуза // Лучшая научная статья 2017. Сборник статей XIII Международного научно-практического конкурса: в 2 ч. 2017. Пенза Издательство: «Наука и Просвещение». С.118-121.

7. Печеркина А.А., Сыманюк Э.Э., Умникова Е.Л. Развитие профессиональной компетентности педагога: теория и практика: монография. Урал. гос. пед. ун-т. - Екатеринбург: 2011. - 233 с.

8. Новиков В.Е. Этические аспекты реализации практической составляющей в медицинском образовании // Смоленский медицинский альманах. 2018. №3. C.8-13.

9. Поттер В.Р. Биоэтика: мост в будущее. Киев: Держава, 2002. 216 с.

10. Тернова 0.М. Науково-методичне обгрунтування впровадження принципів біоетики в професійне навчання та практичну діяльність провізорів і фармацевтів: автореф. дис. канд. фармац. наук. - Нац. мед. акад. післядиплом. освіти ім. П.Л. Шупика. К., 2010. - 22 с .

(с) Гараев Марсель Имамутдинович (m_garaev83@mail.ru). 